\title{
ICHDC2019
}

1st International Conference on Humanities Design \& Creativity 2019

Best Western i-City Shah Alam, Malaysia, 18 Dec 2019

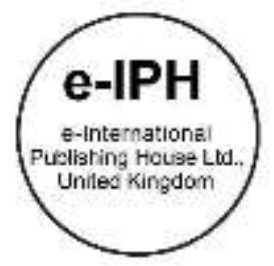

\section{The Role of Education and Schools in Crime Prevention among Child Offenders in Malaysia: Moving forward}

\author{
Nadzriah Ahmad1, Abdul Ghafur Hamid², Saodah Wok³ \\ ${ }^{1}$ Faculty of Law, Universiti Teknologi MARA, 40450, Shah Alam, Selangor, Malaysia \\ 2 Ahmad Ibrahim Kulliyyah of Laws, International Islamic University Malaysia, Gombak, 50728, Malaysia \\ ${ }^{3}$ Kulliyyah of Islamic Revealed Knowledge and Human Sciences, International Islamic University Malaysia, Gombak, 50728, Malaysia \\ nadzriahahmad@gmail.com, ghafur@iium.edu.my, wsaodah@iium.edu.my \\ Tel of 1st Author: +6014-6631466
}

\begin{abstract}
Children subjected to suspensions and expulsions from schools are often more susceptible to truancy and anti-social behaviour. Therefore, the objectives of this paper are (a) to examine the adequacy of the existing legal framework in providing effective crime prevention measures in schools and whether the laws are meeting the international legal framework; and (b) to propose viable crime prevention measures that help address the disciplinary problems in schools. A qualitative study is undertaken to meet these objectives, and the findings from this study can help schools develop more holistic measures in addressing disciplinary cases of children in schools.
\end{abstract}

Keywords: disciplinary cases; punishments, restorative justice; juvenile justice system.

eISSN: 2398-4287 ( 2021. The Authors. Published for AMER ABRA cE-Bs by e-International Publishing House, Ltd., UK. This is an open access article under the CC BYNC-ND license (http://creativecommons.org/licenses/by-nc-nd/4.0/). Peer-review under responsibility of AMER (Association of Malaysian Environment-Behaviour Researchers), ABRA (Association of Behavioural Researchers on Asians) and cE-Bs (Centre for Environment-Behaviour Studies), Faculty of Architecture, Planning \& Surveying, Universiti Teknologi MARA, Malaysia.

DOI: https://doi.org/10.21834/ebpj.v6iSI5.2928

\subsection{Introduction}

In Malaysia, under Section 2 (a) of the Child Act 2001 (hereinafter referred to as the 2001 Act), a child is defined as a person who is below the age of eighteen (18) years old. Many studies recognised the various factors which lead to children committing disciplinary problems in schools. These disciplinary problems are particularly prevalent among children studying in secondary schools in Malaysia, and truancy is cited as the highest form of behavioural misconduct committed by children in schools (Ching, et al. 2015). Truancy is defined (by the Federal Territory Education Department of Kuala Lumpur) as circumstances where children are absent from school on official school days without giving any reasons or written reasons from parents, guardians or medical doctors (Azhar Shah, et al. 2012). Other than truancy, children's most frequent disciplinary problems in schools are bullying, theft, possession of prohibited items in schools, gangsterism (Tie, 2012), and vandalism (Zainal \& Mohamad Salleh, 2008). Among factors that have been cited that contributed to truancy among children in secondary schools are personal factors such as lack of motivation (Sueb \& Izam, 2016; Abdullah, et al. 2018) and self-limitation such as lack of language proficiency, lack of religious knowledge and impulsive behaviour (Sueb \& Izam, 2016; Nik Ruzyanei et al. 2009). Closely related to personal factors that contribute to truancy among children in school is family factors such as lack of family support, low socio-economic background and broken families (Nik Ruzyanei et al. 2009; Sueb \& Izam, 2016; Abdullah, et al. 2018). In addition, environmental factors such as teachers' negative attitudes towards children in school also make them feel not valued. This negative attitude has also contributed to children causing disciplinary problems in schools.

eISSN: 2398-4287 ( 2021. The Authors. Published for AMER ABRA cE-Bs by e-International Publishing House, Ltd., UK. This is an open access article under the CC BYNC-ND license (http://creativecommons.org/licenses/by-nc-nd/4.0/). Peer-review under responsibility of AMER (Association of Malaysian Environment-Behaviour Researchers), ABRA (Association of Behavioural Researchers on Asians) and cE-Bs (Centre for Environment-Behaviour Studies), Faculty of Architecture, Planning \& Surveying, Universiti Teknologi MARA, Malaysia.

DOI: https://doi.org/10.21834/ebpj.v6iSI5.2928 
Additionally, peer factors have influenced children's behaviours, especially when they skip school (Sueb \& Izam, 2016). Negative peer influence has been cited as the most dominant factor that leads to truancy cases among children (Abdullah, et al., 2018) and a significant discipline problem in schools in Malaysia (Mansor, et al. 2017). Moreover, influence from media and communication and exposure to violent and uncensored movies, pornographic scenes and websites are also contributing factors to disciplinary problems in schools and can potentially lead children to come into contact with the juvenile justice system (Mansor, et al. 2017). In this connection, it is reported that the majority of child offenders only have the minimum UPSR (Primary School Assessment Test) qualification when they were first arrested, followed by those who have PMR (Lower Secondary Assessment) qualification. In Malaysia, children are qualified to sit for the UPSR test and the PMR examination when they are twelve (12) years old and fifteen (15) years old, respectively. Hence, these children come into contact with the formal justice system at a young age, and they can be vulnerable to the adverse effects of the juvenile justice system in Malaysia (Ahmad, 2017). In 2017, the Royal Malaysian Police identified 402 schools in Malaysia that has the most disciplinary problems (Category 1 schools) and schools with disciplinary as well as drug problems (Category 3 schools) (The New Straits Time, 18 August 2017). Given the high numbers of children who attend primary and secondary schools in Malaysia, it is integral to have effective crime prevention measures and policies to ensure that schools' disciplinary problems are addressed effectively and children are prevented from committing a crime at an early age. Research has shown that school-going children subjected to disciplinary measures such as suspension are more vulnerable in coming into contact with the criminal justice system. Moreover, children who have undertaken a series of suspensions have a higher likelihood of getting arrested (Mowen and Brent, 2016). The objectives of this paper are (a) to examine the adequacy of the existing legal framework in providing effective crime prevention measures in schools across Malaysia and whether the laws are in line with the provisions in the Convention on the Rights of the Child 1989 (hereinafter referred to as the CRC 1989) and the international legal framework; and (b) to propose other viable crime prevention measures that can help the school address the disciplinary problems in schools.

\subsection{The Legal Framework}

The laws governing the juvenile justice system in Malaysia are encapsulated in Part X of the 2001 Act that outlines the procedures and trials governing Malaysia's juvenile justice system. Further, Section 2 (b) of the 2001 Act provides that concerning criminal proceedings, a child is a person who has attained the age of criminal responsibility according to Section 82 of the Penal Code. In the absence of specific provisions governing the juvenile justice system in the 2001 Act, reference can be made to the Criminal Procedure Code provisions (hereinafter referred to as the CPC). It is also to be noted that Part X of the 2001 Act does not specify any crime prevention measures that can be undertaken by the stakeholders before children come into contact with the juvenile justice system in Malaysia. Crime prevention among children is only mentioned in Section 3 (2) (c) of the 2001 Act, but its scope is limited to one of the roles that the National Council for Children can play in ensuring that children are prevented from engaging in immoral or criminal acts. However, in Malaysia, the principal laws that govern the education system in Malaysia are encapsulated in the Education Act 1996. (Tie, 2012; Nor Muhammad \& Rashid 2017; Nagaratnam \& Yeo, 2018). Additionally, disciplinary cases in schools are governed by the Education (School Discipline) Regulations 1959, as well as guidelines and administrative circulars issued by the Ministry of Education to facilitate school teachers in dealing with disciplinary cases among children to ensure that they exercise their powers within the legal framework permissible by the laws (Nor Muhammad \& Rashid 2017).

Within the national legal framework, the type of punishments that can be meted out in addressing school disciplinary problems depend on the severity of children's misconduct. Under the circular issued by the Ministry of Education, the children's misconduct in schools can fall under any one of the three categories, which is light, moderate or severe forms of misconduct (Nor Muhammad \& Rashid 2017). In response to these disciplinary problems, schools can employ the following methods in dealing with children in schools: (a) first, demerit points allow the schools to accumulate the points at the end of the semester and punishment is imposed on children based on the accumulated points. Examples of minor forms of misconduct that warrant this method's employment are coming late to schools, willful disobedience against teachers' instructions, failure to complete homework on time, and causing distractions in the classrooms. However, these points can be deducted through points gained from the reward system if the children demonstrate exemplary behaviour in schools such as volunteering to maintain the cleanliness of the classroom (Tie, 2012); (b) second, the use of corporal punishment is permitted in more specific cases of severe misconduct such as children involvement in fights and causing damage to schools' properties. The employment of corporal punishment is strictly governed by Section 5 (1) of the Education (School Discipline) Regulations 1959 to ensure that schools adhere to due process in law. Before carrying out this form of punishment, prior notice and informal hearings for children must take place to safeguard the rights of the children and to ensure that actions taken are in good faith and to educate the children (Tie, 2012); (c) third, the use of suspension and expulsion are reserved for more severe misconduct cases committed by children. Students' suspension usually occurs between one to three days, and students are usually subjected to this short time to maintain school discipline (Tie, 2012). However, when children are subjected to expulsion due to breaking the schools' rules and regulations, they are permanently removed or excluded from the school (Nagaratnam \& Yeo, 2018). Like corporal punishment, before suspension or expulsion can occur, the schools must adhere to the laws prescribed in the Education (School Discipline) Regulations 1959. Schools must also ensure that before the decisions to expel or suspend are made, the primary objectives drive these decisions to maintain the school discipline (Tie, 2012).

In addition to the domestic laws, Malaysia has also acceded to the CRC 1989 in 1995, which imposed obligations on Malaysia to carry out the provisions in the CRC 1989, under Article 4 of the CRC. Articles 37 and 40 of the CRC 1989 outlines child offenders' rights in the juvenile justice system. States Parties need to meet at least the minimum guarantees and safeguards in the CRC 1989 to ensure 
children are protected at all juvenile justice system stages. Moreover, Article 28 of the CRC 1989 highlighted the importance of children's rights to education and the obligation of Member States to encourage regular attendance at schools and provide measures to reduce the drop-out rates of children from schools. Additionally, the Committee on the CRC in its General Comment No. 24 (2019), entitled, Children's Rights in the Child Justice System (hereinafter referred to as General Comment No. 24), specifically highlighted that one of the objectives of General Comment No. 24 is to emphasise the significance of prevention and early intervention for children and to ensure that children's rights are protected at all stages of the juvenile justice system (Para 6 of the General Comment No. 24). Ensuring that there are sufficient crime prevention measures in place at schools is crucial to ensure that children are not part of the drop-out rates. Crime prevention is defined as strategies and measures that can be undertaken to reduce the risk of crimes occurring and minimise their potentially harmful effects on society by addressing the multiple causes of crime. In the context of children, the United Nations Model Strategies and Practical Measures on the Elimination of Violence against Children in the Field of Crime Prevention and Criminal Justice 2014 (hereinafter referred to as the Model Strategies and Practical Measures 2014) recognise that the education sector (in addition to the child protection, social welfare and health sectors) play a complementary role to the justice system in crime prevention as well as providing a protective environment to children and responding to violence against children in the juvenile justice system (Para 2, Model Strategies and Practical Measures 2014, Para 83 of the General Comment 20 on the Implementation of the Rights of the Child During Adolescents, 2016). United Nations Guidelines for the Prevention of Juvenile Delinquency 1990 (hereinafter referred to as the Riyadh Guidelines) also highlighted the critical role of education in developing specialised prevention programmes for children at social risks at schools. In particular, schools should have crime prevention programmes to curb the spread of alcohol, drugs and other substance abuse by children. However, these programmes can only be effective if teachers are adequately trained to deal with these disciplinary issues in schools. Student bodies play active roles in participating in these programmes by disseminating the information to schools (Para 25 of the Riyadh Guidelines). Not only crime prevention programmes are essential in schools, teachers, staff and student bodies should also be sensitised to the issues, needs and perceptions of children in schools, especially those belonging to the underprivileged, disadvantaged, ethnic, minority and low-income groups (Para 27 of the Riyadh Guidelines).

\subsection{Methodology}

The findings discussed in the article are derived from the qualitative research design, which aims primarily in obtaining in-depth views and opinions from respondents who are part of the juvenile justice system in Malaysia (Creswell, 2009). This research's primary data is obtained from the semi-structured interviews conducted with respondents (25 respondents/stakeholders from eight different sectors in the juvenile justice system in Malaysia) who participated in the study, using validated interview protocols prepared for the respondents (Yaqin, 2007). Conducting semi-structured interviews allows an interviewer to probe complex answers and elicit better participation from the respondents (Yaqin, 2007). The twenty-five (25) officers were selected through purposive sampling due to their position as stakeholders when dealing with child offenders in the Malaysian juvenile justice system. In purposive sampling, each sample is chosen for a particular purpose because of the unique position attributed to the sample, such as the respondents were chosen based on their roles and experience dealing with child offenders in the juvenile justice system in Malaysia (Bachman and Schutt, 2011). Following the semi-structured interviews, data analysis of the qualitative study commenced when data from the interviews were transcribed to get an overall view of the respondents. These data were then categorised into various coding and themes. Subsequently, the researcher examines the relationships between these coding and themes to establish whether the current crime prevention measures at schools adequately prevent children from getting involved with crime. Finally, inductive reasoning is formed based on the mapping of themes established earlier following the respondents' interviews (O'Leary 2010). Among the limitations in undertaking this research is the respondents' inaccessibility in participating in the semi-structured interviews due to their working engagements. Moreover, some meetings were rescheduled at the eleventh hour because of the respondents pressing work engagements elsewhere. Thus, in overcoming the limitations above, the researchers made the appropriate follow-up with the respondents before the scheduled semistructured interviews to ensure that the sessions were conducted as planned.

\subsection{Findings}

Some of the key findings derived from the qualitative study highlighted that children who are fifteen years and above and involved in crime are those who played truant or were absent from school, and for some children, they have already dropped out from school. Hence, truancy behaviour can lead to children's early involvement in crime when there are no viable alternatives to punishments and effective crime prevention programmes in schools.

\subsection{Discussions}

Schools should serve as an essential platform for the establishment of resource and referral centres in providing children with medical counselling, and other services, especially for children with special needs and those suffering from abuse, neglect, victimisation and exploitation. Further, schools should also provide special assistance to children who have problems attending school and are at risk of drop-outs (Para 27 of the Riyadh Guidelines). While it is recognised that the forms of punishments highlighted in the preceding paragraphs are in place to facilitate the smooth teaching and learning process in schools, all disciplinary actions taken must be carried 
out in line with the prescribed laws and regulations to ensure that schools abide with the principles of fairness when dealing with children (Tie, 2012). For instance, the severe effects of expulsion on children can help them feel hopelessness and hatred towards the schools since they are not given a second chance to better themselves (Nagaratnam and Yeo, 2018). Furthermore, research has shown that out-of-school suspension and expulsion are recognised as risk factors that place children vulnerable to adverse developmental outcomes (Skiba, Arredondo and Williams, 2014) such as grade retention, lowered school performance, dropping out, increased delinquency and crime (Gerlinger, 2020) as well as involvement with the criminal justice system (Gerlinger, 2020; Mallett, 2016). Additionally, a recent study demonstrated that crime increases in neighbourhoods with a high local suspension of students from schools in the same area (Gerlinger, 2020).

Hence, before schools decide to impose punishments such as suspensions and expulsions on children for more serious offences, it is vital to give considerations to the following factors; (a) the effects on students learning process during the period of absence from school; (b) the presence of elements of biases and discrimination in the decision-making process; and (c) strict compliance with rules of natural justice when dealing with children (Tie, 2012). In light of the preceding paragraphs, schools in Malaysia have taken the necessary steps to address the disciplinary problems in schools in the forms of the demerit system, corporal punishment, and suspension and expulsion. Research has also shown that schools have adopted other methods such as counselling (Kok, et al. 2012; Kok \& Low, 2017). Additionally, other forms of counselling, such as the psychological intervention module, have contributed to reducing disciplinary cases in schools (Ahmada \& Salim, 2011). Art therapy has helped improve children's well-being with disciplinary issues (Wan Hamat \& Abu Bakar, 2020). Even though counselling is recognised as a well-established guidance programme in secondary schools and serves as an essential tool in dealing with children with disciplinary cases, it still largely remains unpopular at schools due to the misconceptions that counselling services are only meant for troubled students. These services are rendered based on needs-driven rather than being integrated with the whole school system. Hence, counselling services can be more effective and more beneficial for the children when collaborative approaches between school administrators, parents and the community are undertaken in tackling disciplinary issues in schools (Kok, et al. 2012; Kok \& Low, 2017). Moreover, it has also been argued that the current punitive legal framework is no longer practical to address the underpinning reasons behind children's involvement in disciplinary cases in schools. It is further contended that there is a need to review the Education (School Discipline) Regulations 1959 and the relevant circulars in connection with the types of punishment that can be imposed on children in schools, particularly the framework governing corporal punishment (Balasingam, Mohamad Nor and Ahmad Shah, 2019).

\subsection{Conclusions and Recommendations}

Disciplinary cases involving children in schools are unique to Malaysia, but similar problems exist in other jurisdictions. However, in other jurisdictions such as Australia, New Zealand, Canada and the United States, the schools have departed from the punitive approach of punishing dealing with disciplinary cases. Instead, the restorative justice approach has been adopted (Fronius et al. 2019). Restorative justice often serves as viable alternatives to schools' traditional approach, particularly exclusionary disciplinary actions such as suspension or expulsion (Fronius, et al. 2019). One of the most common restorative justice practices that have been implemented to address disciplinary cases in schools is restorative circles which give opportunities for children to connect and engage in discussions with affected parties that help them realise the impact of their misconduct on others and strive to be accountable for their wrongdoing (Amstutz \& Mullet, 2005).

Furthermore, in the school context, restorative practices provide children with opportunities for individual development and social responsibility as part of creating a socially responsible school culture (Macready, 2009; Morrison \& Vaandering, 2012) as well as contributing to positive behaviour among children, including academic improvements (Short, Case \& Mckenzie, 2018). Many scholars opined that school restorative justice practices have successfully reduced suspension rates (Song \& Swearer 2016; Hashim, Strunk \& Dhaliwal, 2018) and contribute to school performance and a positive learning environment (Song \& Swearer 2016). Additionally, reported studies also indicate that restorative justice practices help improve children's social relationships and reduced discipline referrals and serve as essential violence prevention and intervention tools in schools (Katic, Alba \& Johnson, 2020). Therefore, it is imperative for schools to consider other viable alternatives to punishment, such as restorative justice practices as part of the whole school approach in dealing with disciplinary cases in schools that can positively impact children. Due to the harmful effects of punishments on children and the misconceptions of counselling services offered in schools, considering restorative justice practices can demonstrate the schools' seriousness in helping at-risk children, preventing incidences of school drop-outs, and children's potential involvement with the juvenile justice system. Adopting these alternative measures will help schools and the government meet the minimum requirement in Article 28 of the CRC 1989 and other international legal frameworks in addressing the disciplinary cases at schools more effectively. The findings of this research can hopefully contribute significantly to the establishment of more effective crime prevention measures in schools. However, for future research, children's participation from schools as respondents can be crucial to determine whether crime prevention measures effectively prevent children from coming into contact with the juvenile justice system in Malaysia.

\section{Acknowledgements}


The authors gratefully acknowledge the Ministry of Education of Malaysia's help in providing the Exploratory Research Grant Scheme (ERGS). The authors are also thankful to Associate Professor Dr Zaiton Hamin, Faculty of Law, Universiti Teknologi MARA, Shah Alam, Selangor, for heading the research grant.

\section{References}

Abdullah, M.A., Syed Salim, S.S., \& Mohamed Arip, M.A. (2018). Factors that Influenced the Problems of Truancy Among Secondary School Students. International Journal of Academic Research in Business \& Social Sciences, 8 (3), E-ISSN 2222-6990.

Ahmad, N (2017). Diversion of Child Offenders from the Criminal Justice System in Malaysia and Reforms of the Child Act 2001: Lessons from New Zealand. PhD Thesis. The International Islamic University of Malaysia.

Ahmada, S \& Salim, S. (2011). The Effect of Psychological Intervention in Reducing Disciplinary Cases Among Malaysian Secondary School Students. Procedia-Social and Behavioural Sciences, 30, 2592-2596.

Amstutz, L.S., \& Mullet, J.H. (2005). The Little Book of Restorative Discipline for Schools: Teaching Responsibility; Creating Caring Climates. PA: GoodBooks.

Azhar Shah, S., Abdullah, A., Noor Aizuddin, A., Hassan, M.R., Safian, N., Hod, R. \& Mohd Amin, R. (2012). Psycho-Behavioural Factors Contributing to Truancy among Malay Secondary School Students in Malaysia. ASEAN Journal of Psychiatry, 13(2)

Balansingam, U., Mohamad Nor, A. \& Ahmad Shah, S.S. (2019). Corporal Punishment in Malaysian Public Schools: Legal and Educational Perspectives. IIUMLJ, 27 (2), $525-548$.

Ching, L.M., Jiar, Y.K., \& Jaffri, H. (2015). Developing Discipline Among Students Through Social-Emotional Learning: A New Model to Prevent and Reduce Behaviour Problems. Journal of Education and Vocational Research, 6(2), 80-90.

CRC/C/GC/24 Committee on the Convention on the Rights of the Child General Comment No. 24. (2019). Children's Rights in the Child Justice System.

Creswell, John, W. (2009). Research Design Qualitative, Quantitative and Mixed Methods Approach. USA: Sage Publications.

Fronius, T., Hammond, S.D., Persson, H., Guckenbergh, S., Haerly, N., \& Petrosino, A. Gerlinger, J. (2019). Restorative Justice in US Schools: Un Updated Research. San Francisco, United States.

Hashim, A.K., Strunk, K.O., \& Dhaliwal, T.K. (2018). Justice for All? Suspension Bans and Restorative Justice Programs in the Los Angeles Unified School District. Peabody Journal of Education, 93(2), 174-189.

Katic, B., Alba, L.A., \& Johnson, A.H. (2020). A Systematic Evaluation of Restorative Justice Practices: School Violence Prevention and Response. Journal of School Violence.

Kok, J.K., Low, S.K., Lee, M.G \& Cheah, P.K. (2012). The Provisions of Counselling Services in the Secondary Schools of Perak State, Malaysia. 2nd International Conference on Social Science and Humanity IPEDR, 31.

Kok, J.K., \& Low, S.K. (2017). Proposing a Collaborative Approach for School Counselling. International Journal of School \& Educational Psychology, 5(4), 281-289.

Mallet, C.A. (2016). The School-to-Prison Pipeline: From School Punishment to Rehabilitation Inclusion. Preventing Social Failure: Alternative Education for Children and Youth, 60 (4), 296-304.

Mansor, N.A, Sanasi, J, Mohd Noor, M.Y., Mohammad Nasir, N., \& Ab. Wahab, J. (2017). Teacher Perceptions of Managing Indiscipline amongst At-Risk Teenage Students: A Malaysian Study. International Journal of Advanced and Applied Sciences, 4(5), 112-119.

Macready, T. (2009). Learning Social Responsibility in Schools: A Restorative Practice. Educational Psychology in Practice, 25 (3), 211-220.

Morrison, B.E. \& Vaandering, D. (2012). Restorative Justice: Pedagogy, Praxis and Discipline. Journal of School Violence, 11 (2), $138-155$.

Mowen, T. \& Brent, J. (2016). School Discipline as a Turning Point: The Cumulative Effect of Suspension on Arrest. Journal of Research in Crime and Delinquency, 53 (5), 628-653.

Nagaratnam, N. \& Yeo, K.J. (2018). Exploring the Effect of Expulsion on Student's Psycho-Social Development. Malaysian. Asian Social Science, 14 (11), E-ISSN 19112025.

Nor Muhammad, N.N. \& Rashid, Z.A. (2017). Regulations and Law on Governing Students Discipline in Malaysia. Malaysian Online Journal of Education, 1 (1), 1-11.

Nik Ruzyanie, N.J., Wan Salwina, W.I., Tuti Iryani, M.D., Rozhan, M.R., Shamsul, A.S., \& Zasmani, S. (2009). Psychological factors Influencing Truancy in High-Risk Secondary Schools in Kuala Lumpur. Malaysian Journal of Psychiatry, 18 (2), 01-08-09.

Short, R., Case, G., \& McKenzie, K. (2018). The Long Term Impact of a Whole School Approach of Restorative Practice: The Views of Secondary School Teachers. Pastoral Care in Education, 36(4), 313-324. 
Skiba, R.J, Arredondo, M.I., \& Williams, N.T. (2014). More Than a Metaphor: The Contribution of Exclusionary Discipline to a School-to-Prison Pipeline. Equity \& Excellence in Education, 47 (4), 546-564.

Song, S.S., \& Swearer, S.M. (2016). The Cart Before the Horse: The Challenge and Promise of Restorative Justice Consultation in Schools. Journal of Educational and Psychological Consultation, 26 (4), 313-324.

Sueb, R., \& Izam, M.M. (2016). Excellent Teachers' Perceptions of the Causes of Disciplinary Problems Among Secondary School Students. INCULT Proceedings, 465480 .

Tie, F. (2012). Corporal Punishment, Suspension and Expulsion for Misconduct in Malaysian Schools. Education Law Journal, 1, 32-38.

United Nations General Assembly Resolution A/RES/45/112 (1990). United Nations Guidelines for the Prevention of Juvenile Delinquency (Riyadh Guidelines).

Wan Hamat W.M.B. \& Abu Bakar, A.Y. (2020). Art Therapy As Counselling Modality to Help Delinquent Students. Journal of Counselling, Education and Society, 1(1), $35-41$.

Yaqin, A (2007). Legal Research and Writing. Malaysia: Lexis Nexis.

Zainal, K., Mohamad Salleh, N. (2008). The Implementation of the Penalty System Program for Vandalism in School: A Case Study. International Journal of Learning, 14(9), 123-131. 